\title{
ANALYSIS OF MAGNESIUM CONTENT AND PHOSPHORUS AS FERTILITY INDICATORS IN THE POST-TSUNAMI SEAGRASS ECOLOGY SYSTEM IN THE PALU BAY COASTAL AREA
}

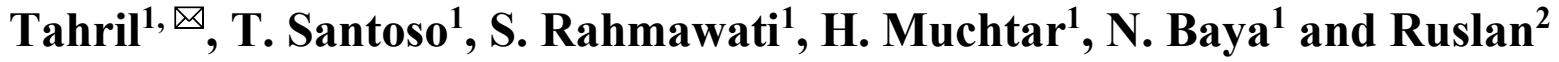 \\ ${ }^{1}$ Departement of Mathematic's and Natural Sciences Education, Faculty of Teacher Training and \\ Education, Tadulako University, Jl. Soekarno Hatta Km 9 City of Palu, 94118, Central Sulawesi, \\ Indonesia \\ ${ }^{2}$ Departement of Mathematic's and Natural Sciences, Faculty of Mathematics and Natural \\ Sciences, Tadulako University, Jl. Soekarno Hatta Km 9 City of Palu, 94118, Central Sulawesi, \\ Indonesia \\ ${ }^{\square}$ Corresponding Author: tahril0608@gmail.com
}

\begin{abstract}
The content of magnesium and phosphorus has been observed and analyzed as fertility indicators in the ecological system (seagrass). Seagrass and sediment samples were taken from the coastal area of Palu Bay in Indonesia. Magnesium mineral analysis was carried out using atomic absorption spectrometry (AAS) while phosphorus mineral analysis used ultraviolet (UV)-visible spectrometry. The results showed; (1). The status of abundance and association of seagrass beds affects the magnesium concentration and phosphorus, (2). Magnesium concentration and phosphorus in the seagrass ecosystem were higher in the very abundant abundance status compared to those with the abundant abundance status and the less abundance of seagrass status (3). Seagrass beds associated with mangroves have higher magnesium concentration and phosphorus in their ecosystem, both in sediments and in seagrass plants. The Magnesium concentration and phosphorus in the seagrass ecosystem will be even lower in association with mangroves coral reefs, and (4). Magnesium and phosphorus minerals in seagrass can be bioindicators of the fertility of seagrass beds. It is hoped that efforts to determine essential trace minerals in seagrass plants can be carried out continuously to show that seagrass plants in waters can be an indicator of the fertility of these waters.
\end{abstract}

Keywords: Seagrass, Magnesium, Phosphorus, Fertility Indicators, Ecology.

RASĀYAN J. Chem., Vol. 14, No.3, 2021

\section{INTRODUCTION}

The Palu Bay tsunami at the end of 2018 caused severe damage to both social and natural structures including coastal areas as one of the providers of abundant ecological resources. The coastal area of Palu Bay with a coastline of $\pm 47 \mathrm{~km}$ has considerable ecological resources. In this coastal area, there are quite extensive seagrass beds with varying density levels of $10-62.1 \%$ with a potential of around 40 hectares. The types of seagrass found, identified 8 species from 2 genera. Seagrass beds are generally found in tidal areas after mangrove forests, the highest density is found around the Banawa coastal area with a cover of about $62.1 \%$ and the lowest is found around the coastal area of Tondo with a cover of around $8.2 \%{ }^{1,2}$ If the condition of the seagrass beds in the coastal area of Palu Bay is related to the status of the seagrass beds according to the Minister of Environment Decree No. 200 of 2004 concerning the Determination of the Status of Seagrass beds, then the coastal area of Palu Bay has three seagrass beds, namely rich, less rich, and poor.

In general, the abundance, growth, morphology and primary production of seagrass in the waters is determined by the availability of nutrients (including magnesium, phosphorus and iron). ${ }^{3-8}$ The availability of nutrients is very dependent on other marine resources, both mangroves and coral reefs. Seagrass beds associated with mangroves have higher iron concentrations in the ecosystem, in water, sediments, and 
RASĀYAN J. Chem.

Vol. 14 | No. 3 |2056-2061| July - September | 2021

seagrass plants. The iron concentration in the seagrass ecosystem will be lower in association with coral mangroves to linkage with coral reefs. This causes seagrass beds to become bioindicators of water fertility, especially heavy metal, Fe. ${ }^{9}$ In addition, seagrass fat with variations between 0.36 to 1.1 percent and variations in protein between 5.2 (C. serrulata) and 8.3 percent (T. hemprichii) ${ }^{1,2}$

The growth factor of seagrass is very much determined by the adequacy of nutrients in the water, both macro and micronutrients. This nutrient is one of the limiting factors for the growth of seagrass in the waters. $^{4,10-12}$ The main productivity of seagrass and the autotrophic organisms that live in it is determined by the efficiency of the nutrient cycle in the seagrass ecosystem. ${ }^{13-19}$

The distribution pattern of magnesium and phosphorus in the post-tsunami seagrass ecosystem in Palu Bay can be determined quantitatively by analyzing these metals in sediment and seagrass plants, in addition to analyzing other factors, physical and chemical properties of water, which also have a significant effect on increasing levels of these metals.

If the data regarding magnesium and phosphorus metals in the seagrass ecosystem and the factors that influence them can be known, then this data can be used as a basis for estimating damage to the seagrass area. Furthermore, this information can also be used as an alternative solution for efforts to improve overall biodiversity in an ecosystem area.

\section{Material and methods}

\section{EXPERIMENTAL}

The sample of this study was taken from the coastal waters of Palu Bay, Central Sulawesi Province. Sample preparation and analysis of Mg (using AAS PG Instrument 990) and P minerals (UV-Vis PG Instrument T90) were carried out in the Chemistry Laboratory of Tadulako University.

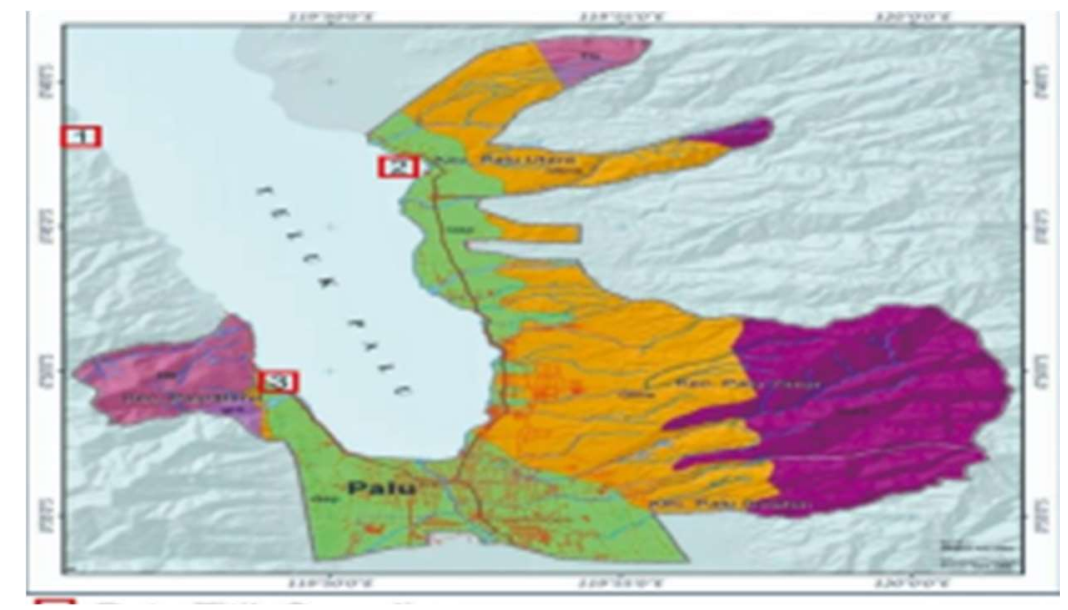

Fig.-1: Map of Sampling Points

\section{General Procedure}

Sediment sampling was carried out at three observation points in each status of the seagrass beds, taking into account the depth of the waters and the direction of currents in the seagrass ecosystem. Two main factors underlie the distribution of the sampling points, namely the depth factor that allows sunlight to penetrate and the depth structure of the coastal area of Palu Bay, Central Sulawesi Province. The sampling times are 1) at low tide, the transition between full moon tides and 2) when the tidal currents are weak. Measurement and sampling of seagrass (Enhalus acorodies species) were carried out simultaneously with sediment sampling.

\section{Detection Method}

The treatment design used is a combination of two factors, namely: 1) seagrass habitat association (L); $\mathrm{L}_{1}$ $=$ mangrove, $\mathrm{L}_{2}=$ mangrove-coral reef, and $\mathrm{L}_{3}=$ coral reef and 2) seagrass status $(\mathrm{S}) ; \mathrm{S}_{1}=$ rich, $\mathrm{S}_{2}=$ less rich, and $\mathrm{S}_{3}=$ poor. So that $3 \times 3 \times 3$ replications were obtained resulting in 27 treatment combinations for each system. The analysis design used was a completely randomized design (CRD). The data obtained were analyzed by univariate variance. The best association and status of seagrass beds in determining the highest 
concentration of $\mathrm{Mg}$ and P metals were used in the LSD test $(\alpha=0.05)$.

\section{Analytical Discussion}

Sediment samples were taken from the area of the seagrass beds (front, center, and outer) which were embedded in the sediment at a predetermined point and covered with rubber stoppers using a corer sampler. The number of samples taken at each point of observation ranged from 5-6 samples, then homogenized so that only 1 sample was obtained per point of observation. Seagrass samples were taken at the same time as sediment sampling. The metal analysis work chart in the sample is shown in Fig.-2.

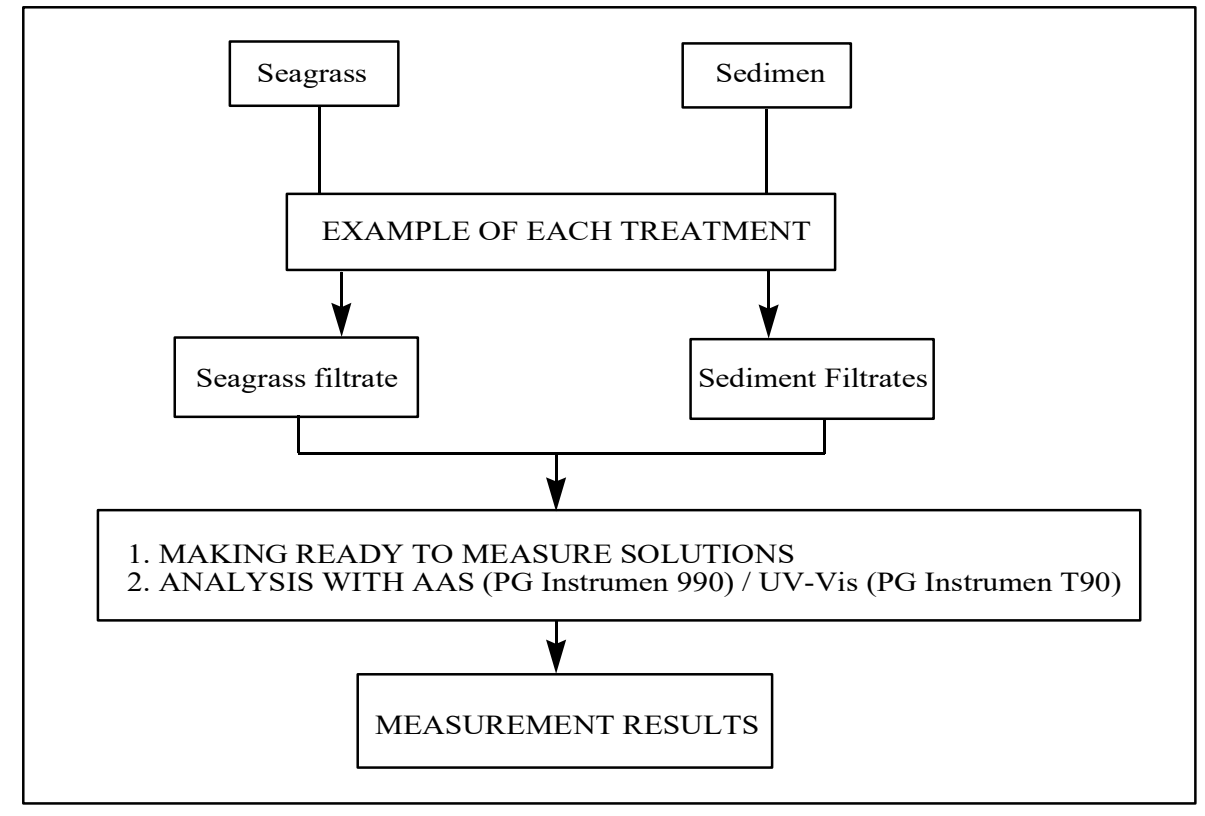

Fig.-2: Work Chart of Mg and P Analysis in a Sample

\section{RESULTS AND DISCUSSION}

The mineral profile of $\mathrm{Mg}$ in the seagrass ecosystem on the coast of Palu Bay fluctuates, for sediments between 865,309-1241,905 ppm and seagrass between 1067,105-1285,714 ppm. Likewise with mineral P, for sediments between 3.68-4.00 ppm and seagrass between 1.28-2.00 ppm (Table-1). This indicates that there has been bioaccumulation of $\mathrm{Mg}$ and $\mathrm{P}$ minerals in sediments and seagrass in the coastal area of Palu Bay. The nutrient content of $\mathrm{Mg}$ in seagrass leaves is very high in the order $\mathrm{Na}>\mathrm{K}>\mathrm{Ca}>\mathrm{Mg}>\mathrm{S}>\mathrm{Fe}>\mathrm{Al}>$ $\mathrm{Si}>\mathrm{Mn}>\mathrm{Zn}$ but there are differences in content between seagrass families, due to environmental factors. In addition, the elemental content of seagrass leaves also shows a correlation with one of the macronutrients $\mathrm{P}$ which is also important for maintaining the productivity and fertility of the seagrass community. ${ }^{20}$ The balance in most waters is affected by the presence of magnesium and calcium. ${ }^{21}$

Analysis of the various effects of $\mathrm{Mg}$ in sediments showing that the effect of interaction with the status of the seagrass beds is significant, The average $\mathrm{Mg}$ concentration is obtained in the combination of fertile seagrass treatments in the mangrove area (L1S1) with an average value of $1241.905 \mathrm{ppm}$, and can be achieved in the interaction of poor seagrass growth in coral reef areas (L3S3) with an average value of $865.309 \mathrm{ppm}$. The effect of $\mathrm{Mg}$ concentration shows that the interaction effect of the association with the status of the seagrass beds is tested real, while the highest average $\mathrm{P}$ concentration is obtained in the treatment of fertile seagrass plants in the mangrove area (L1S1) with an average value of $4.00 \mathrm{ppm}$, and can be achieved in the interaction of seagrass growth poor in coral reef areas (L3S3) with a mean value of $3.68 \mathrm{ppm}$. The results of this study also illustrate that the concentration of $\mathrm{Mg}$ and $\mathrm{P}$ in the sediment is quite high, this indicates that there has been metal accumulation in the sediment. The accumulation of heavy metals into the sediment is influenced by the type of sediment. ${ }^{22-24}$

Analysis of the various effects of $\mathrm{Mg}$ concentration in seagrass shows that the effect of interaction with the status of seagrass beds is significant, the average $\mathrm{Mg}$ concentration of seagrass is obtained in fertile areas 


\section{RASĀYAN J. Chem.}

Vol. 14 | No. 3 |2056-2061| July - September | 2021

in mangrove areas (L1S1) with an average value of $1285.714 \mathrm{ppm}$, and can be achieved in the interaction of seagrass growth in poor areas in coral reef areas (L3S3) with an average value of $1067.105 \mathrm{ppm}$. The effect of $\mathrm{Mg}$ concentration shows that the interaction effect of the association with the status of the seagrass beds is proven, the highest $\mathrm{P}$ concentration in seagrass is found in the association of seagrass with mangroves (L1S1), which is $2.00 \mathrm{ppm}$ and the lowest $\mathrm{P}$ concentration is in the association of seagrass with coral reefs (L3S3), that is $1.28 \mathrm{ppm}$. Seagrass beds adjacent to mangrove margins have higher nutrient availability. ${ }^{25}$

Table-1: Average Mg and P Concentrations in the Ecosystem seagrass in the Coastal Area of Palu Bay

\begin{tabular}{c|c|c|c|c}
\hline \multirow{2}{*}{ Combination } & \multicolumn{3}{|c}{ The Average Mineral Concentration of each Object observed } \\
\cline { 2 - 5 } & \multicolumn{2}{|c}{ Sediment } & \multicolumn{2}{c}{ Seagrass } \\
\cline { 2 - 5 } & $\mathrm{Mg}(\mathrm{ppm})$ & $\mathrm{P}(\mathrm{ppm})$ & $\mathrm{Mg}(\mathrm{ppm})$ & $\mathrm{P}(\mathrm{ppm})$ \\
\hline L1S1 & $1241.905 \pm 37.027$ & $4.00 \pm 1.23$ & $1285.714 \pm 58.213$ & $2.00 \pm 0.98$ \\
\hline L1S2 & $1211.429 \pm 33.025$ & $3.89 \pm 1.06$ & $1257.143 \pm 50.346$ & $1.89 \pm 0.83$ \\
\hline L1S3 & $1106.356 \pm 23.076$ & $3.86 \pm 1.03$ & $1252.786 \pm 48.345$ & $1.76 \pm 0.54$ \\
\hline L2S1 & $1176.103 \pm 29.234$ & $3.84 \pm 1.21$ & $1189.686 \pm 30.423$ & $1.68 \pm 0.52$ \\
\hline L2S2 & $1018.324 \pm 21.321$ & $3.80 \pm 1.43$ & $1158.140 \pm 27.489$ & $1.63 \pm 0.50$ \\
\hline L2S3 & $987.682 \pm 18.321$ & $3.78 \pm 1.61$ & $1150.682 \pm 25.789$ & $1.56 \pm 0.44$ \\
\hline L3S1 & $1076.303 \pm 24.402$ & $3.72 \pm 1.35$ & $1094.126 \pm 24.632$ & $1.32 \pm 0.41$ \\
\hline L3S2 & $896.420 \pm 14.045$ & $3.68 \pm 1.55$ & $1072.120 \pm 23.579$ & $1.28 \pm 0.42$ \\
\hline L3S3 & $865.309 \pm 11.098$ & $3.68 \pm 1.44$ & $1067.105 \pm 22.431$ & $1.28 \pm 0.41$ \\
\hline
\end{tabular}

L1: Seagrass-Mangrove Association, L2: Seagrass-Mangrove-Coral Reef Association, L3: Seagrass-Coral Reef Association; S: Seagrass Status (Cover) S1: (> 60\%), S2: (39-59\%), S3: $(<39 \%)$

Description of the results of data processing shows that the factor of the fertility status of the seagrass beds, both in association with mangroves, coral reef mangroves, and coral reefs can be an important indicator in determining the quality of the marine environment. Various previous research results indicate that seagrass plants can relatively filter the stability of the waters because they contain macromolecular compounds that can accumulate metals in the waters. Argued that the seagrass plant contains protein with a complete amino acid composition, also contains complete fatty acids, and contains quite high levels of $\mathrm{Fe}, \mathrm{Mn}$, and $\mathrm{Cu}$ minerals. ${ }^{1,2,9,11,26,27}$

Responding to the presence of metal elements in the seagrass ecosystem, there are three important mechanisms in the response of metal elements including $\mathrm{Mg}$ and $\mathrm{P}$ to seagrass plants in the aquatic environment, namely accumulation, toxicity, and lack/absence, absorption of $\mathrm{Mg}$ and $\mathrm{P}$. If the presence of these metal elements is excessive in the ecosystem seagrass will decrease the totality of amino acids. One of the causes of the increased availability of phosphorus for seagrass uptake is the dissolution of carbonate sediments. This causes an increase in seagrass growth. $\mathrm{Mg}$ is very important in the photosynthetic process of seagrass because it is the central atom of the chlorophyll molecule. ${ }^{9,11,12,20,24}$

Magnesium is absorbed to form chelates with ligands certain in the cell and citric acid appears to be the most important ligand for transporting magnesium through the xylem, finally being delivered in plant tissues, especially the structural components of the chloroplast membrane system, in addition, magnesium also accumulates to form protein-Mg complexes (plastocyanin) which are an important $\mathrm{t}$ or between cytochrome $\mathrm{f}$ and photosystem II. However, excessive absorption of $\mathrm{Mg}$ and $\mathrm{P}$ will affect the reduction of chlorophyll biosynthesis, this indicates that photosynthesis is very sensitive to the toxicity of $\mathrm{Mg}$ and $\mathrm{P}$. $\mathrm{Mg}^{+2}$ ions can diffuse into the chloroplast as a result, the leaves grow old. ${ }^{10,16,28-30}$

\section{CONCLUSION}

Based on the results of research on the ecological studies of magnesium and phosphorus minerals in seagrass ecosystems, it is concluded that the things are as stated in the formulation below:

1. The status of abundance and association of seagrass beds affects the concentration of magnesium and phosphorus.

2. The concentrations of magnesium and phosphorus in the seagrass ecosystem are higher in the status with very abundant abundance compared to the status of seagrass with abundant abundance and less abundance of seagrass status. 
RASĀYAN $J$. Chem.

Vol. 14 | No. 3 |2056-2061| July - September | 2021

3. Seagrass beds associated with mangroves have higher concentrations of magnesium and phosphorus in their ecosystem, both in sediments and in seagrass plants. The concentrations of magnesium and phosphorus in the seagrass ecosystem will be even lower in their association with mangroves and coral reefs.

4. Magnesium and phosphorus metals in seagrass can be bioindicators of the fertility of seagrass beds.

5. Efforts can be made to determine essential trace metals in seagrass. Considering that iron, manganese and copper are essential trace metals (micro), it is necessary to further study the relationship between essential trace metals (macro), macronutrients, the nutrient cycle of seagrass plants as well as damage to other ecosystem resources in aquatic areas.

\section{ACKNOWLEDGEMENT}

We would like to express our deepest gratitude to fellow researchers, especially those at Tadulako University for their support and assistance for this research and those who have helped the smooth running of this research.

\section{REFERENCES}

1. Tahril and A. Noor, Journal of Physics Conference Series, 1242, 012010(2019), https://doi.org/10.1088/1742-6596/1242/1/012010

2. Tahril, P. Taba, N.L. Nafie, A. Noor, Ratna, and M.Z. Muzakkar, IOP Conference Series Earth and Environmental Science, 382, 012018 (2019), https://doi.org/10.1088/1755-1315/382/1/012018

3. P.L.A. Erftemeijer and J.J. Middelburg, Marine Ecology Progress Series, 95(1), 187(1993), https://doi.org/10.3354/meps095187

4. P.L.A. Erftemeijer, J. Stapel, J.E.M Smekens and W.M.E. Drossaert, Journal of Experimental Marine Biology and Ecology, 182(1), 123(1994), https://doi.org/10.1016/0022-0981(94)90215-1

5. D.M. Alongi, D. Murdiyarso, J.W. Fourqurean, J. Kauffman, A. Hutahaean, S. Crooks, C. Lovelock, J. Howard, D. Herr, and M. Fortes, Wetlands Ecology and Management, 24(1), 3(2015), https://doi.org/10.1007/s11273-015-9446-y

6. R.K Unsworth, R.A. Rappe, B.L. Jones, Y.A.L. Nafie, A. Irawan, U.E. Hernawan, A.M. Moore and L.C.C. Unswoth. Science of The Total Environmental, 634(1), 279(2018), https://doi.org/10.1016/j.scitotenv.2018.03.315

7. F. Sidik, B. Supriyanto, H. Krisnawati, and M.Z. Muttaqin, Wiley Interdisciplinary Reviews: Climate Change, 9(4), e529(2018), https://doi.org/10.1002/wcc.529

8. U.M. Nehren and P. Wicaksono, Estuarine Coastal and Shelf Science, 214, 185(2018), https://doi.org/10.1016/j.ecss.2018.09.022

9. Tahril, P. Taba, N.L. Nafie, A. Noor, Ratna, and M.Z. Muzakkar. Asian Journal of Applied Sciences 13(1), 1(2020a), https://doi.org/10.3923/ajaps.2020.1.7

10. G. Hernan, I. Castjon, J. Terrados, and F. Tomas, Oecologia, 189(3), 719(2019), https://doi.org/10.1007/s00442-019-04364-6

11. J. Romero, K.S. Lee, M. Perez, M.A. Mateo and T. Alcoverro, Nutrient Dynamics in Seagrass Ecosystems, 227, Seagrass Biology Ecology and Conservation Springer Verlag, The Netherlands (2006).

12. E.B. Barbier, S.D. Hacker, C. Kennedy, E.W. Koch, A.C. Stier, and B.R. Silliman, Ecological Monographs, 81(2), 169(2011), https://doi.org/10.1890/10-1510.1

13. K. Hillman, D.J Walker, A.W.D. Larkum, and A.J. McComb, Aquatic Plant Studies, 2, 635(1989).

14. K.S. Lee, S.R. Park and Y.K. Kim, Journal of Experimental Marine Biology and Ecology, 350(2), 144(2007), https://doi.org/10.1016/j.jembe.2007.06.016

15. Z. Jiang, L. Cui, L. Songlin, C. Zhao, Y. Wu, Q. Chen, Y. Shuo, J. Li, J. He, Y. Fang, C. Premarathne and X.H. Huang, Global Ecology and Conservation, 22, 2020, https://doi.org/10.1016/j.gecco.2020.e01035

16. M.H. Long, P. Berg, K.J. McGlathery and J.C. Zieman, Marine Ecology Progress Series, 529, 75(2015), https://doi.org/10.3354/meps11314 
RASĀYAN J. Chem.

Vol. 14 | No. 3 |2056-2061| July - September | 2021

17. F. Truinio, J. Bourgoure, A. Koenders, B. Laverock, C. Säwström and G.A. Hyndes. International Society for Microbial Ecology Journal, 12(11), 2796(2018), https://doi.org/10.1038/s41396-018-0218$\underline{6}$

18. C.M. Duarte, H. Kennedy, N. Marbà and I. Hendriks, Ocean and Coastal Management, 83, 671688(2013), https://doi.org/10.1016/j.ocecoaman.2011.09.001

19. M. Gullström, L.D. Lyimo, M. Dahl, G.S. Samuelsson, M. Eggertsen, E. Anderberg, L.M. Rasmusson, H.W. Linderholm, A. Knudby, S. Bandeira, L.M. Nordlund and M. Björk, Ecosystems, 21(3), 551(2018), https://doi.org/10.1007/s10021-017-0170-8

20. J. A. Vonk, F. O. H. Smulders, M. J. A., Christianen, and L. L. Govers, Marine Pollution Bulletin, 134, 123(2018), https://doi.org/10.1016/j.marpolbul.2017.09.066

21. T. Suresh, and N.M. Kottureshwara, Rasayan Journal of Chemistry, 2(1),221(2009)

22. L. Mao, L. Liu, N. Yan, F. Li, H. Tao, H. Ye and H. Wen, Chemosphere 243, 125359(2019), https://doi.org/10.1016/j.chemosphere.2019.125359

23. P.C Emenike, I.T. Tenebe, P. Jarvis, D.O. Omole, O. Afolayan, C.U. Okeke and I.K. Emenike, Niger Environmental Pollution, 265, 114795(2020), https://doi.org/10.1016/j.envpol.2020.114795

24. K. Karlsson, M. Viklander, L. Scholes and M. Revitt, Journal of Hazardous Materials, 178(1), 612(2010), https://doi.org/10.1016/j.jhazmat.2010.01.129

25. M. S. Koch, and C. J. Madden. Marine Ecology Progress Series, 219, 109(2001).

26. Tahril, P. Taba, N.L. Nafie, and A. Noor, Current Chemistry Letters, 9(3), 113(2020), https://doi.org/10.5267/j.ccl.2019.11.001

27. Y. Sun, Z. Song, H. Zhang, P. Liu, and X. Hu, Marine Enviromental Research, 162, 105174(2020), https://doi.org/10.1016/j.marenvres.2020.105174

28. F.B. Salisbury and C.W. Ross. Plant Physiology 2. Intitute of Technology Bandung, Bandung (2003).

29. O.L. Lange, P.S. Nobel, C.B. Osmond. and H. Ziegler, Physiological Plant Ecology, 1, (1983).

30. C.C. Ogbaga, Regulation of Photosynthesis in Sorghum in Response to Drought, Faculty of Life Sciences University of Manchester, Manchester (2014).

[RJC-6484/2021] 